"It is [the] two-track labor market, rather than austerity, that is the biggest threat to the persistence of the European social model."

\title{
Europe's Social Safety Net Under Pressure
}

\section{GIULIANO BONOLI}

S ince the oil shocks of the 1970s, Europe has more or less constantly worried about the sustainability of its economic and social model, which is based on high levels of income redistribution and extensive social insurance. Over the years, though, the standard view has emphasized the resilience of European welfare states. True, some of the most generous programs were cut back in the 1980s and 1990s, depending on the country, but at the same time benefits rapidly expanded in other areas such as childcare services. Perhaps most importantly, the key defining features of the European social modelprotection against the main life-course risks of old age, sickness, and unemployment-remained strong. European welfare systems proved to be as resilient as expected during the economic crises of the 1970s and 1990s.

Arguably, things will be different this time. The world is still recovering from the post-2008 financial crisis, and some European countries are dealing with anemic economic growth, high unemployment, and troublesome public finances. The reforms undertaken in response to this crisis have affected the core of the European social model to a much greater extent than previous adjustments, especially in some Southern European countries, sometimes referred to as "peripheral." For the first time since the end of World War II, cohorts of Italians and Spaniards are moving toward retirement without adequate social protection, and it is very difficult to see how, in the current context, this trend can be reversed.

Only a return to reasonable levels of economic growth in the peripheral countries will allow Europe to preserve its economic and social model. Future reforms should be based on this under-

GIULIANO BONOLI is a professor of social policy at the University of Lausanne. He is a coauthor of The Politics of the New Welfare State (Oxford University Press, 2012). standing and promote economic growth in both direct and indirect ways.

\section{LONG-TERM IMBALANCES}

Europe has entered the post-2008 world with a series of unresolved challenges confronting its welfare states. The first and most important is population aging. Fertility rates (the number of children a woman is likely to have during her reproductive life) plummeted across the continent from the 1960s through the 1980s. In most countries, they have remained very low ever since. Germany has had a rate of 1.3 to 1.4 children per woman since the 1980s. In Southern Europe, fertility rates fell to even lower levels (Italy's was 1.2 in the 1990s). They have slightly recovered since then, mostly thanks to higher rates among immigrant women.

This long-term decline in fertility rates, combined with longer life expectancies, has resulted in a serious funding problem for the generous oldage pension systems in place throughout the continent. Pensions were particularly attractive (and thus costly) in continental Southern and Western Europe, with the retirement age sometimes set as low as 60 or even lower.

A second crucial trend concerns changes in the labor market, an issue faced not only by Europe but by all advanced economies. Technological progress and the transfer of many productive activities to emerging markets (China above all) have resulted in labor demand in advanced economies being highly skewed toward the upper end of the skill distribution. In their European offices, firms need engineers, marketing specialists, accountants, and so forth. Meanwhile, there is steadily declining demand for low-skilled and unskilled labor, including all sorts of machine operators and manual workers.

To some extent, this development in labor demand has occurred in tandem with a gen- 
eral upgrading of skills among workers in most advanced economies. However, there is still a big imbalance in the low-skilled segment of the labor market, where supply vastly exceeds demand. This structural change is a problem for welfare states. Low-skilled individuals have greater difficulty accessing stable employment and are overrepresented in various social programs. This generates higher government spending and problems of exclusion from mainstream society that can be extremely worrisome in the long term.

Furthermore, the imbalance between supply and demand affects the quality of the low-skill jobs that are created. In such a context, wages can be very low-far below what is needed to live a decent life. In response, several European countries, including Britain and Germany, have adopted mandatory minimum wages. But low-wage employment and a generous welfare state do not sit comfortably together. The benefits may give unemployed recipients an incentive to stay on welfare rather than take a job, especially since the available low-skill jobs not only are poorly paid-they tend to be unrewarding, repetitive, and physically demanding as well.

European societies have also become more multicultural over the years. To some extent, this third trend can be understood with reference to aging populations. Given their low fertility rates, many countries would be experiencing population decline were it not for migration. Europe has discovered that managing a multicultural society is not easy. Migrants take some of the (rare) low-skill jobs but are also more likely to end up on welfare. Migrants are overrepresented in many social programs, but they also experience discrimination in the labor market and in society as a whole. Their presence has been exploited by opportunistic political entrepreneurs of the extreme right, who have been very successful in several European countries over the past few years.

\section{ATYPICAL WORKERS}

Finally, a fourth trend that is essential to understanding current developments in European welfare states is the process of "dualization" in the labor markets of several countries, creating different tiers of job protection. In these countries, mostly in continental Western and Southern Europe, labor law traditionally provid- ed very high levels of employment security for all workers. Businesses contemplating collective or individual terminations often face substantial administrative hurdles. In recent years, employers have put pressure on governments to deregulate these highly rigid labor markets and limit job protection rules. Labor market deregulation, however, has met with strenuous opposition from trade unions.

The result is that governments have allowed the introduction of a range of unprotected labor contracts that employers can use as an alternative to the highly protected ones that still exist. These new contract types, sometimes classified as "atypical," consist of temporary contracts, contracts for self-employed individuals, and contracts for jobs at rates of pay below a certain threshold. What these new contracts have in common is the fact that they do not provide protection against dismissal. They generally also do not generate rights to social insurance such as unemployment or retirement benefits.

Dualization represents a major challenge to the European model of society. In countries such as Italy, Spain, France, and Germany, a substantial proportion of job creation since the 1990s has been achieved through the expansion of these types of atypical jobs. As a result, relatively large cohorts of workers are heading toward retirement without accumulating any form of entitlement to a pension.

\section{THE HARD AND THE SOFT}

Europe has entered the post-2008 world with these problems still largely unresolved. They have been compounded by the most severe economic crisis experienced by the global economy since the end of World War II. What's more, the crisis has exposed some faults in the design of the European project that have led to huge imbalances across the continent.

The adoption of the single currency in 1999 by 11 (now 19) member states of the European Union removed an important tool of adjustment from the economic policy repertoires of these countries: devaluation. Throughout the postwar years, soft-currency countries (such as Italy, France, and Greece), could afford comparatively high rates of wage growth and inflation without endangering the competitiveness of their econo- 
mies. They could easily compensate by devaluing their currency every few years.

In contrast, hard-currency countries such as Germany had to keep wage growth, public spending, and inflation under tight control. With the adoption of the euro, Germany and other countries accustomed to living with a hard-currency regime enjoyed a tremendous advantage relative to former soft-currency countries that were totally unfamiliar with the kind of tight discipline in wage growth and public spending that a hardcurrency regime requires.

Putting former soft- and hard-currency countries together in a currency union has generated tremendous tensions and imbalances. On one side are Germany and a few other countries that manage to adhere to the fiscal and wage-growth discipline imposed by the union, and on the other side is the rest of the continent. Because of these imbalances, the impact of the crisis on welfare states differs dramatically between the former hard-currency and soft-currency countries. In Germany, austerity measures were adopted before 2008. Since then, Germany has mostly made adjustments to the welfare system while adopting new measures to boost incomes for the most disadvantaged, such as the introduction of a mandatory minimum wage in 2015 , at 8.50 euros per hour.

Things went differently in the peripheral countries, which were fighting a major debt crisis. They were forced to adopt radical austerity measures that have arguably changed the face of their welfare states.

\section{INSIDERS AND OUTSIDERS}

Austerity was particularly radical in Southern Europe, where reforms made high-cost pension systems less generous. Unlike the previous reforms of the 1990s and 2000s, which were adopted under moderate fiscal pressure, governments this time needed to generate savings immediately. So, for the first time in postwar history, countries including Greece, Portugal, Spain, and Hungary had to cut the pensions of current retirees. Previous reforms usually affected only future retirees while leaving current pensions untouched, reflecting the idea that "acquired rights" to benefits must be protected as if they were property rights.

Some countries also decided to raise the retirement age, which is a highly effective measure to restore a balanced pension budget because it simultaneously increases the number of contributors to state pension funds while decreasing the number of recipients. In recent years, increases in the retirement age were adopted not only in Italy and Greece but also in the Netherlands, Finland, and Denmark. In addition to these radical measures, more typical steps were adopted in several countries, such as increases in payroll taxes earmarked for old-age pensions and reductions in the generosity of benefit indexation for inflation.

Taken together, these reforms are changing the meaning of retirement for many current workers who will either have to work longer or accept considerably lower pensions. One group that is clearly not going to enjoy a comfortable retirement is the relatively large cohort of atypical workers who have entered the labor force since the 1990s in countries with rigid labor markets such as Italy, Spain, and France, where much job creation has consisted of temporary jobs, self-employment, or other forms of atypical work that is not covered well or at all by the welfare state. These workers are suffering from the twin pressures of a more unstable labor market and a less generous public pension system.

Atypical workers are penalized not only in relation to pensions. They are also largely unprotected against most other employment-related social risks, such as unemployment, sickness, and disability. Some commentators describe the labor market and also society at large as dualized, meaning that an increasingly profound division is emerging between insiders and outsiders. Insiders still have access to standard employment protection against dismissal and relatively good levels of social insurance. Outsiders alternate between periods of low-paid employment and unemployment, are not protected by dismissal laws since they work with atypical contracts, and do not receive much protection from the welfare state.

It is this two-track labor market, rather than austerity, that is the biggest threat to the persistence of the European social model. It stems from the inability of European governments to spread the cost of economic adjustment evenly across social classes. Weak governments have imposed losses on weak social groups, with the consequence that they are excluded from the social contract that made Europe a unique place in terms of social cohesion and equality in the second half of the twentieth century.

Who is excluded? It is difficult to clearly identify the outsiders in European welfare states. The notion of dualization is a broad and crude simplification of the real world, and being excluded 
from the European social model is in fact a matter of degrees. However, workers with atypical contracts are systematically overrepresented in disadvantaged groups such as people living in poor households and the long-term unemployed. In general, low-skill status is a common characteristic of outsiders. They also tend to be young, migrants, or individuals saddled by family-related risks such as single parenthood. Members of these groups may experience levels of economic insecurity that are atypical for Europe.

\section{DEREGULATORY COLLUSION}

The trend toward dualization is strongest in continental Southern and Western Europe, particularly in countries like Italy, Spain, and France, but also in Germany. They have followed a common path toward a dualized society. The starting point was a highly rigid labor market. In all these countries, employee protection against dismissal in particular was considered by employers, as well as by most labor economists, to be too strong.

Starting in the 1990s, attempts were made to loosen employment protections. Those attempts were usually blocked by powerful labor unions, which were not averse to staging major strikes and protest actions, most notably in countries such as France and Italy that have a strong tradition of union-led mobilization. Faced with such seemingly insurmountable opposition, governments decided to take an easier route. Rather than deregulate standard employment contracts, they would create new varieties with few protections and allow employers to use these contracts instead of the standard ones.

At one stage, Italy had over 30 different types of employment contracts. One of them was the standard, open-ended, well-protected contract. The others were various forms of atypical contracts for temporary and self-employed work. In Germany, atypical contracts known as mini-jobs existed before the 1990s, and were meant to provide extra income to students and housewives. They were deregulated in the 1990s, and have since become common for all types of work. In both countries, much of the employment expansion during the late 1990s and 2000s was based on such contracts, not the standard ones.

Labor unions, while fiercely opposed to the deregulation of the standard employment con- tract, acquiesced in these reforms. Their core members did not see their protection reduced. In a way, dualization can be seen as the result of a form of collusion between governments and unions. Governments were under pressure from business groups, as well as from international and supranational organizations such as the Organization for Economic Cooperation and Development and the $\mathrm{EU}$, to deregulate the labor market. Unions had to protect the interests of their members. The result was the concentration of the cost of reform on the weakest in society, those who we now term "outsiders."

\section{MULTI-ETHNIC FUTURE}

Increased levels of migration have also been a major trend throughout Europe in the past several years, rising to unprecedented levels in 2015. The geopolitical instability on Europe's doorstep, partly a result of the Arab Spring uprisings that began in 2011, has prompted hundreds of thousands of asylum seekers to head north. Europe was totally unprepared to deal with such a massive inflow of people, which is understandable. The sheer numbers involved make the problem daunting.

However, Europe has a longerterm problem that relates to migration. There are few countries on the aging continent that can avoid population decline without resorting to mass immigration. France and perhaps a few Nordic countries have managed over the past decade or so to sustain fertility rates close to two children per woman, the level needed to secure the replacement of a population. For most other countries in Europe, without massive immigration the most likely future is one of population decline. With a fertility rate of 1.5 children per woman, each new cohort has a size equal to three-quarters of the previous one. Project this over four or five generations and the population shrinks to a small fraction of what it was before the demographic transition began.

If Europe wants to avoid population decline, it has no other option than to accept mass immigration and turn into a multicultural society. This is not speculation. It is already happening throughout the continent. From Sweden to Italy, from Portugal to Hungary, European countries are becoming increasingly multi-ethnic. The problem is that this process generates huge tensions. Most Europeans are used to living in ethnically and 
religiously homogeneous societies. Many of them have trouble accepting the presence of different lifestyles, values, and behaviors.

\section{WELFARE CHAUVINISM}

Those tensions are magnified by the fact that immigration usually occurs in an economic context in which relatively large sections of the population have experienced social suffering because of economic transformations, or, as has recently been the case, during times of crisis. The losers in these processes are essentially lower-middleclass individuals and families. The labor market has become particularly difficult for them because technological progress has destroyed many semiskilled jobs (such as secretarial and back-office staff positions). As a result, they are often forced to accept employment in the low-skilled segment of the labor market, and enter into direct competition with low-skilled migrants. Competition between low-to-mid-skilled natives and migrants also happens in other contexts, such as the housing market.

One result is that the losers in the current economic transformation are easily mobilized by political entrepreneurs who promise to stop the trend toward a multicultural society and severely limit migration. Anti-immigration parties have had success in several European countries over the past decade. France's National Front has won more than 25 percent of the popular vote in its best showings at the ballot box, and is kept out of power only by an electoral system in which mainstream parties cooperate against it. In the Nordic countries, anti-immigrant parties have also done well over the past few years, winning between 10 and 20 percent of the vote in the most recent elections.

Regarding the welfare state, these parties tend to share a common view, known in the specialist literature as "welfare chauvinism." Unlike other right-wing parties, they favor a generous welfare state but one that is limited to nationals and gives little to migrants. The financial problems that are forcing European welfare states to cut benefits would be solved, they insist, through reducing the number of claimants by halting immigration. Welfare chauvinism appeals to the losers in the ongoing economic transformation because it promises them good-quality social protection and services while excluding a new class of losers.

There are, of course, several problems with the welfare chauvinism vision. The most important is its inability to deal with the demographic problem. If dependency on the welfare state is increasing, this is not so much because of immigration. An aging population is a much bigger factor. As larger cohorts reach retirement age, spending on old-age pensions increases. With an aging society, cutting migration is not only an ineffective way to restore the fiscal balance of the welfare state. It is counterproductive, because it reduces the size of the workingage population. An aging population needs as many working-age people as possible to sustain the welfare state with their tax contributions.

\section{THE GROWTH CURE}

It is difficult today to talk about what is happening to welfare states in Europe in terms of common trends because we are seeing a divergence between the countries that can keep up with Germany (in productivity growth and competitiveness) and the rest. The former include Austria, the Netherlands, and the Nordic countries. Tellingly, these are all countries that had already more or less tightly linked their national currencies to the Deutsche mark before the introduction of the single currency. This accustomed them to the discipline imposed by a fixed exchange rate pegged to the industrial giant of Europe. These countries have to deal with many of the same demographic and economic challenges facing other European countries, but they can do so on a sound economic footing.

Then there are the peripheral countries, which were accustomed to devaluing their currencies periodically against the Deutsche mark. They include Italy, Spain, and Greece, to name a few. These countries have been losing competitiveness over the years, failing to contain increases in wages and public spending, and are now unable to devalue to cope with the crisis.

A return to economic growth seems to be a necessary condition for the preservation of the European welfare state. But how? Many interventions that can bring growth back are outside the remit of the welfare state: investment in research and development; expansion of education and 
high-quality vocational training; wage moderation; an accommodating monetary policy; good infrastructure; social stability.

Nonetheless, the welfare state can make a contribution to stronger growth. It should provide a fair level of income replacement to those who cannot work, without undermining work incentives with overly generous benefits. It should provide training and other assistance to those who are outside the labor market, so that they can find new jobs. It should provide free child-care services and other benefits for working people, such as tax credits, so that parents can more easily reconcile work and family obligations.

The welfare state does not need to be a problem weighing on European economies. It can be part of the solution to their current woes, and it can act as a catalyst of economic growth. In order to do so, however, it must change. The welfare state that Europe needs will be based somewhat less on income protection and more on investment, less on income transfers and more on services. Investing in children and in people's human capital-their education and skills—should be a top priority.

This vision, sometimes referred to as a "social investment" welfare state, is promoted by many experts and international agencies. However, investment-oriented social policies have failed to generate the kind of mass support that is needed to push politicians to act. Yet if Europe wants to leave the crisis behind, stop economic decline, and avoid growing internal divisions, it must be prepared to invest massively in its own people. 